\title{
EX 33 ON GOD'S FACE: A LESSON FROM THE ENOCHIC TRADITION
}

Exodus 33:18-23 depicts Moses who asks the Lord to show him His glory. Instead the Lord agrees to proclaim his name before Moses, telling him that it is impossible for a human being to see God's face.

In recent scholarship this prominent motif of Moses' story has become a stumbling block for students of the Hebrew Bible. Currently most biblical scholars agree upon apparent difficulties in the literary-critical analysis of this section of Exodus. M. Noth comments that «a literary-critical analysis of Exodus 33 is probably impossible». ${ }^{1} \mathrm{~B}$. Childs confirms that there are several fundamental exegetical problems with Exodus 33:18-23. «The most difficult one is to determine the role of this passage in its larger context».2

The internal logic of the passage about the Divine face is also problematic. The whole narrative about God's פנים in Ex 33 is quite perplexing. Ex כ3:11 informs a reader that God would speak to Moses face to face (פים (אל פנים as a man speaks with his friend. A few verses later, in 33:14-15, God promises Moses that His face will go (פני ילכו) with him. In the context of these promises and early testimonies about «face-to-face» relationships, it comes as a surprise that in 33:20 the Lord suddenly rejects Moses' request to see His face (לא תוכל לראת אתדפניפ"י).

It is clear that the anthropomorphic tradition about the divine face in Ex 33 has a fragmentary character. ${ }^{3}$ It may well contain polemics between the anthropomorphic position of the $\mathrm{J}$ source and the Deuteronomic theology of the divine name: instead of the seeing of God's face the Lord offers Moses to the hearing of His name. ${ }^{4} \mathrm{M}$. Noth observes that Ex 33 can be seen as «a conglomeration of secondary accretions» ${ }^{5}$

${ }^{1}$ M. Noтн, History of Pentateuchal Traditions (Englewood Cliffs, 1972) 31, n. 114.

${ }^{2}$ B. S. ChILDs, The Book of Exodus. A Critical, Theological Commentary (Philadelphia, 1974) 595.

${ }^{3}$ A. F. Campbell and M. A. O'Brien placed Ex 33 within the nonsource texts. Cf. A. F. CAmpbell, M. A. O'Brien, Sources of the Pentateuch: Texts, Introductions, Annotations (Minneapolis, 1993) 263.

${ }^{4}$ The Old Testament materials reveal complicated polemics for and against anthropomorphic understanding of God. Scholars agree that the anthropomorphic imagery of the Hebrew Bible was «crystallized» in the tradition, known to us as the Priestly source. Moshe Weinfeld, Deuteronomy and the Deuteronomic School (Oxford,

${ }^{5}$ Noтн, History of Pentateuchal Traditions... 31, n. 114. 
The apparent difficulties one encounters in clarifying the concept of the divine face within the context of the known sources of the Pentateuch call for an investigation of the broader biblical and extrabiblical traditions where this motif could be possibly preserved in its extended form. Implicitly linked to the «original» Exodus motif, these later «interpretations» might provide some additional insights which may help us better understand the fragmentary tradition preserved in chapter 33. This study will focus on one of the possible echoes of Ex 33 - the theophanic tradition of the divine countenance preserved in the corpus of the Enochic writings.

\section{The Face of the Lord}

The Slavonic Apocalypse of Enoch, a Jewish text, apparently written in the first century $\mathrm{CE}$, contains two striking theophanic descriptions involving the motif of the divine face. The first one occurs in 2 Enoch 22 which portrays Enoch's encounter with the Lord in the celestial realm. Enoch recounts:

I saw the view of the face of the Lord, like iron made burning hot in a fire and brought out, and it emits sparks and is incandescent. Thus even I saw the face of the Lord. But the face of the Lord is not to be talked about, it is so very marvelous and supremely awesome and supremely frightening. And who am I to give an account of the incomprehensible being of the

1972) 191. Theological developments of the Priestly tradition demonstrate that the anthropomorphism of the Priestly source is intimately connected with the place of the Divine habitation. In this tradition, «in which the Divinity is personalized and depicted in the most tangible corporeal similitudes», God, who possesses a human form, has a need for a house or tabernacle. (WEINFELD, Deuteronomy and the Deuteronomic School... 191). Weinfeld rightly observes that this anthropomorphic position was not entirely an invention of the Priestly source, but derives from early sacral conceptions found in the early sourses. In these traditions the Deity was sitting in his house ensconced between the two cherubim, and at his feet rests the ark, his footstool. In spite of the active promulgation of anthropomorphic concepts in some Old Testament materials, like J, P, and Ezekelian sources, the Hebrew Bible also contains polemics against God's corporeality. Scholars note the sharp opposition of the book of Deuteronomy and the Deuteronomic school to the anthropomorphism of the Priestly source and early anthropomorphic traditions. In their opinion, Deuteronomic school «first initiated the polemic against the anthropomorphic and corporeal conceptions of the Deity and that it was afterwards taken up by the prophets Jeremiah and Deutero-Isaiah». (WeINFELD, Deuteronomy and the Deuteronomic School... 198). In contrast to the anthropomorphic imagery of $\mathrm{J}$ and $\mathrm{P}$, the Deuteronomic school promulgates anticorporeal theology of the divine name with its conception of sanctuary (tabernacle) as the place where only God's name dwells. On Deuteronomic antianthropomorphism, see T. N. D. Mettinger, The Dethronement of Sabaoth. Studies in the Shem and Kabod Theologies (Lund, 1982) (ConBOT, 18); WeInFELD, Deuteronomy and the Deuteronomic School... 191-209. 
Lord, and of his face, so extremely strange and indescribable? And how many are his commands, and his multiple voice, and the Lord's throne, supremely great and not made by hands, and the choir stalls all around him, the cherubim and the seraphim armies, and their never-silent singing. Who can give an account of his beautiful appearance, never changing and indescribable, and his great glory? And I fell down flat and did obeisance to the Lord (2 Enoch 22:1-4, the longer recension). ${ }^{6}$

In chapter 39 Enoch reports this theophanic experience to his sons during his short visit to the earth, adding some new details. Although both portrayals demonstrate a number of terminological affinities, the second account explicitly connects the divine face with the Lord's anthropomorphic «extent». The following account is drawn from the shorter recension of 2 Enoch:

And now, my children it is not from my lips that I am reporting to you today, but from the lips of the Lord who has sent me to you. As for you, you hear my words, out of my lips, a human being created equal to yourselves; but I have heard the words from the fiery lips of the Lord. For the lips of the Lord are a furnace of fire, and his words are the fiery flames which come out. You, my children, you see my face, a human being created just like yourselves; I am one who has seen the face of the Lord, ${ }^{7}$ like iron made burning hot by a fire, emitting sparks. For you gaze into my eyes, a human being created just like yourselves; but I have gazed into the eyes of the Lord, like the rays of the shining $\operatorname{sun}^{8}$ and terrifying the eyes of

${ }^{6}$ F. I. Andersen, 2 (Slavonic Apocalypse of) Enoch // OTP. Vol. 1. 136. The shorter recension of the Slavonic text gives a less elaborated description of the Lord's appearance: «I saw the Lord. His face was strong and very glorious and terrible. Who (is) to give an account of the dimensions of the being of the face of the Lord, strong and very terrible? Or his many-eyed ones and many-voiced ones, and the supremely great throne of the Lord, not made by hands, or those who are in attendance all around him, the cherubim and the seraphim armies, or how unvarying and indescribable and never-silent and glorious is his service. and I fell down flat and did obeisance to the Lord». Cf. ibid. 137. Andersen observes that the absence of the comparison with hot iron in the MSS of the shorter recension shows the embarrassment of scribes over this attempt to describe the Lord's appearance (ibid.).

\section{${ }^{7}$ Slav. мице Господне.}

${ }^{8}$ The important detail of this description is the solar symbolism, which plays an important role in 2 Enoch. The text often uses solar metaphors in various descriptions of angelic beings; e.g., in chapter 1 where Enoch meets two angels with «faces like the shining sun». Later, during his heavenly journey, Enoch sees «a group of seven angels, brilliant and very glorious with faces more radiant than the radiance of the sun». The images of fire and light are often involved in these solar descriptions of angelic hosts. The text pictures «...glorious and shining and many-eyed stations of the Lord's servants... and of the ranks of powerful fireborn heavenly armies». Andersen rightly observes that «fire and light are fundamental elements in the physics of 2 Enoch». Andersen, 2 Enoch... 104. 
a human being. You, my children, you see my right hand beckoning you, a human being created identical to yourselves; but I have seen the right hand of the Lord, beckoning me, who fills heaven. You see the extent of my body, the same as your own; but I have seen the extent of the Lord, ${ }^{9}$ without measure and without analogy, who has no end... To stand before the King, who will be able to endure the infinite terror of the great burning (2 Enoch 39:3-8). ${ }^{10}$

In both theophanic descriptions the notion of the Lord's «face» plays a crucial role. It is not a coincidence that in both of them the «face» is associated with light and fire. In biblical theophanies smoke and fire often serve as a divine envelope that protects mortals from the sight of the divine form. Radiant luminosity emitted by the Deity fulfills the same function, signaling the danger of the direct vision of the divine form. Luminosity also represents the screen which protects the Deity from the necessity of revealing its true form. Scholars note that in some theophanic traditions God's form remains hidden behind His light. ${ }^{11}$ The hidden כבוד is revealed through this light, which serves as the luminous screen, «the face» of this anthropomorphic extent. 2 Enoch's theophanies which use the metaphors of light and fire may well be connected with such traditions where the divine «extent» is hidden behind the incandescent «face», which covers and protects the sovereignty of the Lord.

In 2 Enoch 39:3-6 the «face» is closely associated with the divine «extent» and seems to be understood not simply as a part of the Lord's body (His face) but as a radiant façade of His anthropomorphic «form». ${ }^{12}$ This identification between the Lord's face and the Lord's «form» is reinforced by an additional parallel pair in which Ehoch's face is identified with Enoch's «form»:

You, my children, you see my face, a human being created just like yourselves; but I am one who has seen the face of the Lord, like iron made burning hot by a fire, emitting sparks.... And you see the form of my body, the same as your own: but I have seen the form (extent) of the Lord, without measure and without analogy, who has no end (2 Enoch 39:3-6).

\section{${ }^{9}$ Slav. WLLAтtue Iocmoane.}

${ }^{10}$ MSS of the longer recension do not demonstrate substantial differences with this description.

${ }^{11}$ April De Conick's pioneering research shows that in Enochic traditions God's form remains hidden behind his light. A. De Conick, Seek to See Him: Ascent and Vision Mysticism in the Gospel of Thomas (Leiden, 1996) (SVC, 33) 104-105.

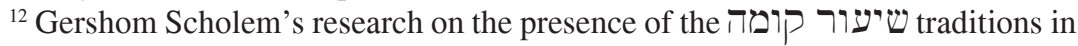
2 Enoch 39 helps to clarify the «anthropomorphic» character of the Lord's «extent» in 2 Enoch. See G. Scholem, The Age of Shiur Komah Speculation and a Passage in Origen // IDEM, Jewish Gnosticism, Merkabah Mysticism, and Talmudic Tradition (New York, 1965) 36-42; IDEM, Origins of the Kabbalah (Princeton, 1990) 20. 
The association between the divine face and divine form in 2 Enoch 39:3-6 alludes to the biblical tradition from Ex 33:18-23 where the divine panim is mentioned in connection with his glorious divine form - God's Kavod: ${ }^{13}$

Then Moses said, «Now show me your glory (כבדך)». And the Lord said, «I will cause all my goodness to pass in front of you, and I will proclaim my name, the Lord, in your presence... but», he said, «you cannot see my face (פכ), for no one may see me and live».

It is clear that in the biblical passage the impossibility of seeing the Lord's face is understood not simply as the impossibility of seeing the particular part of the Lord but rather as the impossibility of seeing the complete range of His glorious «body». The logic of the whole passage, which employs such terms as God's «face» and God's «back», suggests that the term panim refers to the «forefront» of the divine extent. The imagery of the divine face found in Psalms ${ }^{14}$ also favors this motif of the identity between the Lord's face and His anthropomorphic «form». For example, in Ps 17:15 the Lord's face is closely associated with His form or likeness (תמונה):

As for me, I shall behold your face (פני (פני ${ }^{15}$ in righteousness; when I awake, I shall be satisfied with beholding your form (תמונת (ת). ${ }^{16}$

It is evident that all three accounts, Ex 33:18-23, Ps 17:15, and 2 Enoch 39:3-6, represent a single tradition in which the divine face serves as the terminus technicus for the designation of the Lord's anthropomorphic extent.

${ }^{13}$ The term דוב can be translated as «substance», «body», «mass», «power», «might», «honor», «glory», «splendor». In its meaning as «glory» דב usually refers to God, his sanctuary, his city, or sacred paraphernalia. The Priestly tradition uses the term in connection with God's appearances in the tabernacle. P and Ezekiel describe כבוד as a blazing fire surrounded by radiance and a great cloud. M. WEINFELD, כבוד // TDOT. Vol. 7. 22-38.

${ }^{14}$ On the Face of God in Psalms see: S. Balentine, The Hidden God: The Hiding Face of God in the Old Testament (Oxford, 1983) 49-65; W. EICHrodT, Theology of the Old Testament. 2 vols (Philadelphia, 1967) Vol. 2. 35-39; M. Fishbane, Form and Reformulation of the Biblical Priestly Blessing // JAOS 103 (1983) 115-121; J. REINDL, Das Angesicht Gottes im Sprachgebrauch des Alten Testaments (Leipzig, 1970) (ETS, 25) 236-237; M. Sмiтн, Seeing God in the Psalms: The Background to the Beatific Vision in the Hebrew Bible // CBQ 50 (1988) 171-183.

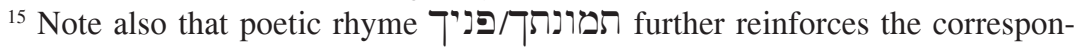
dence between the face and the form of God in this passage.

${ }^{16}$ Although the passage uses a different terminology, namely, the term תמונדה,

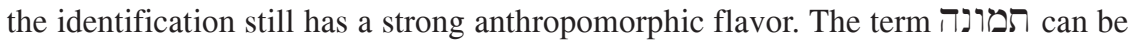
translated as form, likeness, semblance, or representation. 
Apparently, all these accounts deal with the specific anthropomorphic manifestation known as God's Kavod. ${ }^{17}$ The possibility of such identification is already hinted at in Ex 33 where Moses who asks the Lord to show him His Kavod receives the answer that it is impossible for him to see the Lord's «face». The correlation of the divine face with «likeness» (תמונה) in Ps 17:15 can be also an allusion to Kavod, which in Ez 1:28 is described as «the likeness of the glory of the Lord (דמות כבוד יהוה)).

There is another early Mosaic account which correlates the Sinai encounter with Kavod. This important tradition, found in the fragments of the drama «Exodus» written by Ezekiel the Dramatist, depicts Moses' experience at Sinai as the vision of God's anthropomorphic Kavod: ${ }^{18}$

I dreamt there was on the summit of mount Sinai

A certain great throne ( $\theta \rho o ́ v o v ~ \mu \varepsilon ́ \gamma \alpha v$ ) extending up to heaven's cleft,

On which there sat a certain noble man

Wearing a crown and holding a great scepter in his left hand. ${ }^{19}$

W. Meeks observes that this passage may be safely taken as a witness to traditions of the second century BCE, since it was quoted by Alexander Polyhistor who lived around $80-40 \mathrm{BCE} \cdot{ }^{20}$ It means that by the second century BCE Moses' association with Kavod, hinted at in Ex 33, was already surrounded by an elaborate imagery, in which the Throne of Glory played a crucial role.

2 Enoch 22 further strengthens this theophanic pattern in which the encounter with the Divine Face is understood as the vision of God's throne. The text gives a number of evidences which prove that the anthropomorphic «extent», identified with the divine face, indeed represents His Kavod. The theophany of the divine countenance in the Slavonic apocalypse is surrounded by a peculiar Kavod imagery, which plays a prominent role in the Ezekelian account. The following parallels are noteworthy:

1. The theophany of the divine face took place in the highest of the heaven. ${ }^{21}$ The highest of the heaven is a traditional place of God's Throne, the

${ }^{17}$ Contra W. Eichrodt who insists that the panim had no connection with the Kavod. He argues that the two concepts derive from different roots, and were never combined with one another. Cf. EICHRODT, Theology of the Old Testament... Vol. 2. 38.

${ }^{18}$ P. W. van der Horst observes that Ezekiel the Dramatist's vision of God in human shape seated on the throne is based on the first chapter of the biblical Ezekiel. Cf. P. W. van DER Horst, Moses' Throne Vision in Ezekiel the Dramatist // JJS 34 (1983) 24.

${ }^{19}$ C. R. Holladay, Fragments From Hellenistic Jewish Authors. 4 vols. (Atlanta, 1989) (Texts and Translations, 30; Pseudepigrapha Series, 12) Vol. 2. 363.

${ }^{20} \mathrm{~W}$. MeEks, The Prophet-King: Moses Traditions and the Johannine Christology (Leiden, 1967) (SNT, 14) 149. Cf. also Holladay, Fragments From Hellenistic Jewish Authors... Vol. 2. 308-312.

${ }^{21}$ Andersen, 2 Enoch... 136-37. 
abode of His Glory. A later account found in 3 Enoch tells us that «In ${ }^{c}$ Arabot there are 660 thousands of myriads of glorious angels, hewn out of flaming fire, standing opposite the throne of glory. The glorious King covers his face, otherwise the heaven of ${ }^{c}$ Arabot would burst open in the middle, because of the glorious brilliance...». ${ }^{22}$

2. The theophanic description in 2 Enoch 22 refers to «His many-eyed ones», האופנים ה, the Wheels, the special class of the Angels of the Throne who in Ezekiel 1:18 are described as the angelic beings «full of eyes (מל את עינים).

3. A reference to the «many-voiced ones» probably alludes to choirs of angelic hosts surrounding the Throne.

4. Finally, in 2 Enoch 22 there is a direct reference to the throne of the Lord, which occupies a central place in the theophanic description, and is pictured as «supremely great and not made by hands». ${ }^{24}$ The Throne of Glory is surrounded by the armies of the angelic hosts, the cherubim and the seraphim, with «their never-silent singing». ${ }^{25}$

\section{Moses' Face}

Previous research shows that the correlation between God's face and his luminous form (his glorious Kavod) was already implicitly articulated in Ex 33. The Enochic theophany found in 2 Enoch further strengthens this connection, giving a theophanic description of the Lord's face as his terrifying «extent» which emits light and fire.

The important detail of these two accounts is the «danger motif» — the warnings about the peril of seeing the Deity. Both of them contain specific references to the harmful effect this theophanic experience has on the mortals who dare to behold the Divine face. In Ex 33:20 the Lord warns Moses about the danger of seeing His face: «You cannot see my face, for no one may see me and live». The motif of peril is further reinforced by the Lord's instructions in 33:22 where he commands Moses to hide himself into a cleft in the rock and promises to protect the prophet with His hands.

The «danger motif» also looms large in 2 Enoch. In 2 Enoch 39, immediately after his description of the theophany of the face, Enoch gives warning to his children about the danger of this theophanic experience:

Frightening and dangerous it is to stand before the face of an earthly king, terrifying and very dangerous it is, because the will of the king is death and

\footnotetext{
${ }^{22}$ P. S. AleXAnder, 3 Enoch // OTP. Vol. 1. 305.

${ }^{23}$ Andersen, 2 Enoch... 137.

${ }^{24}$ Ibid.

${ }^{25}$ Ibid.
} 
the will of the king is life. How much more terrifying [and dangerous] it is to stand before the face of the King of earthly kings and of the heavenly armies, [the regulator of the living and of the dead]. Who can endure that endless misery? (2 Enoch 39:8). ${ }^{26}$

The «danger motif» in Ex 33 and in 2 Enoch implicitly suggests that both of these accounts support the idea that the human being actually can see the face of God. M. Weinfeld argues that the warning about the danger of seeing the Deity usually affirms the possibility of such an experience. In his observations about antianthropomorphic tendencies of Deuteronomy, Deutero-Isaiah and Jeremiah, he points to the fact that these texts demonstrate a lack of usual warnings about the danger of seeing the Deity found in pre-Deuteronomic books. He concludes that it happened because the Deuteronomic school cannot conceive of the possibility of seeing the Deity. ${ }^{27}$

The possibility of theophany hinted at in 2 Enoch and Ex 33 might suggest that Exodus' account implicitly asserts that Moses could see the divine form. ${ }^{28}$ The distinctive details in the depiction of Moses' face in Ex 34 may further support this conclusion. But before we explore this motif, let us again return to the narrative of 2 Enoch.

From this Enochic account we learn that the vision of the Divine face had dramatic consequences for Enoch's appearance. His body endures radical changes as it becomes covered with the divine light. The important detail here is that the luminous transformation of Enoch takes place in front of the radiant «face» of the Lord. In 22:6 Enoch reports that he was lifted up and brought before the Lord's face by archangel Michael. The Lord decides to appoint Enoch as שר דפנים, the Prince of the Divine Presence: «Let Enoch come up and stand in front of my face forever». ${ }^{29}$ Further, the Lord commanded archangel Michael to remove Enoch from earthly clothing, anoint him with the delightful oil, and put him into the clothes of the Lord's glory (22:8-9). ${ }^{30}$ The text describes the actions of Michael, who anoints Enoch with the delightful oil and clothes him. The symbolism of light permeates the whole scene; the oil emanates the rays of the glittering sun "greater than the greatest light». ${ }^{31}$ At

${ }^{26}$ Andersen, 2 Enoch... 164.

${ }^{27}$ WeINFELD, Deuteronomy and the Deuteronomic School... 207.

${ }^{28}$ Another «Mosaic» account attributed to J, openly articulates this possibility:

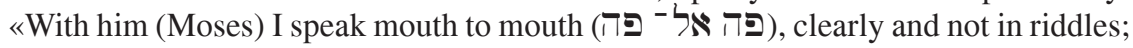
he sees the form (ותממנת) of the Lord». (Num 12:8).

${ }^{29}$ ANDERSEN, 2 Enoch... 139.

${ }^{30}$ Ibid.

${ }^{31}$ Ibid. 138. Jarl Fossum provides a number of allusions to the theme of «shining oil» in 2 Enoch. Cf. J. Fossum, The Image of the Invisible God: Essays on the Influence of Jewish Mysticism on early Christology (Göttingen, 1995) (NTOA, 30) 84. 
the end of this procedure, Enoch «had become like one of the glorious ones, ${ }^{32}$ and there was no observable difference». ${ }^{33}$

In Enoch's radiant metamorphosis before the Divine face an important detail can be found which links Enoch's transformation with Moses' account in Exodus. In 2 Enoch 37 we learn about the unusual procedure performed on Enoch's face on the final stage of his encounter with the Lord. The text informs us that the Lord called one of his senior angels to chill the face of Enoch. The text says that the angel appeared frigid; he was as white as snow, and his hands were as cold as ice. The text further depicts the angel chilling Enoch's face, who could not endure the terror of the Lord, «just as it is not possible to endure the fire of a stove and the heat of the sun...». ${ }^{34}$ Right after this «chilling procedure», the Lord informs Enoch that if his face had not been chilled here, no human being would be able to look at his face. ${ }^{35}$ This reference to the radiance of Enoch's face after his encounter with the Lord is an apparent parallel to the incandescent face of Moses after the Sinai experience in Ex 34. ${ }^{36}$

References to the shining countenance of a visionary found in 2 Enoch return us again to the Exodus story. Ex 34:29-35 portrays Moses after his encounter with the Lord. ${ }^{37}$ The passage tells that «when Moses came down from Mount Sinai ... he was not aware that his face was radiant, because he had spoken with the Lord». The strange logic of the last sentence, which points to anambiguous connection between the speech of the Lord as a cause of Moses' glowing face can be explained by the Enochic theophanic account where «the lips of the Lord are a furnace of fire, and his words are the fiery flames which come out». ${ }^{38}$

${ }^{32}$ Andersen observes that «this motif (Enoch's transformation into the glorious angel) seems to have been influenced by the legend of Moses, whose shining face was a reflection of God's magnificent glory». ANDERSEN, 2 Enoch... 139.

${ }^{33}$ Ibid.

${ }^{34}$ Ibid. 160.

${ }^{35}$ Ibid.

${ }^{36}$ About possible Mesopotamian provenance of this motif cf.: M. HARAN, The Shining of Moses's Face: A Case Study in Biblical and Ancient Near Eastern Iconography [Ex 34:29-35; Ps 69:32; Hab 3:4] // In the Shelter of Elyon (Sheffield, 1984) (JSOT, 31) 159-173; W. Propp, The Skin of Moses' Face - Transfigured or Disfigured? // CBQ 49 (1987) 375-386.

${ }^{37}$ On Moses' traditions see: R. BLOCH, Die Gestalt des Moses in der rabbinischen Tradition // Moses in Schrift und Überlieferung (Düsseldorf, 1963) 95-171; G. W. COATS, Moses: Heroic Man, Man of God (Sheffield, 1988) (JSOTSup, 57); S. HAFEMANN, Moses in the Apocrypha and Pseudepigrapha: A Survey // JSP 7 (1990) 79-104; W. A. Meeks, The Prophet-King: Moses Traditions and the Johannine Christology (Leiden, 1967) (NovTSup, 14); R. PolzIN, Moses and the Deuteronomist: A Literary Study of the Deuteronomic History (New York, 1980).

${ }^{38}$ Andersen, 2 Enoch... 163. 
These parallels between the later Enochic text and the biblical Mosaic account are not inappropriate. As will be demonstrated later, the connection between the Enochic and Mosaic accounts has quite ancient roots. Evidences of the early link between Enoch and Moses includes the already mentioned drama of Ezekiel the Dramatist, which was apparently written during the second century BCE. ${ }^{39}$

W. Meeks ${ }^{40}$ and P. W. van der Horst ${ }^{41}$ observe that the depiction of Moses in the drama of Ezekiel the Dramatist bears some similarities to Enoch's figure in the Enochic traditions. They note a number of remarkable allusions in the drama to the Enochic motifs and themes. These allusions include the following points:

1. Moses's account is depicted as his dream vision in a fashion similar to Enoch's dreams in 1 Enoch and 2 Enoch.

2. In the text Moses is «elevated» by God, who gives him the throne, the royal diadem, ${ }^{42}$ and the scepter.

3. God appointed Moses as an eschatological judge of humankind able to see «things present, past and future» ${ }^{43}$ — the traditional role of Enoch found already in early Enochic booklets.

4. Moses is an «expert» in «a variety of things», including cosmological and astronomical information:

I beheld the entire circled earth

Both beneath the earth and above the heaven,

And a host of stars fell on its knees before me;

I numbered them all,

They passed before me like a squadron of soldiers. ${ }^{44}$

This preoccupation with various meteorological, astronomical and eschatological «secrets» are typical duties of the elevated Enoch which are here transferred to Moses apparently for the first time. ${ }^{45}$

${ }^{39}$ Holladay, Fragments From Hellenistic Jewish Authors... Vol. 2. 312.

${ }^{40}$ MeeKs, The Prophet-King... 147.

${ }^{41}$ VAN DER Horst, Moses' Throne Vision... 21-29.

42 The crowning of Enoch-Metatron became a prominent leitmotif in later Enochic tradition, especially, in 3 Enoch. W. Meeks observes that the enthronement of Enoch-Metatron in 3 Enoch «betrays interesting similarities to Moses' traditions». MeEKs, The Prophet-King... 207. See also van der Horst who observes that «like Moses, Enoch is assigned a cosmic and divine function that involves the wearing of regalia». VAN DER Horst, Moses' Throne Vision... 25.

${ }^{43}$ Holladay, Fragments From Hellenistic Jewish Authors... Vol. 2. 367.

${ }^{44}$ Ibid. 365.

${ }^{45} \mathrm{R}$. H. Charles argued that this transition of Enoch's function to Moses first was made in 2 Apoc. Bar., where God shows Moses «the measures of the fire, also the depths of the abyss, and the weight of the winds, and the number of the drops of rain». APOT. Vol. 2. 514. 
5. Finally, the motif of assigning the seat/throne is a peculiar feature of Enochic literature where Enoch-Metatron is depicted as a scribe ${ }^{46}$ who has a seat (later a throne) in the heavenly realm. ${ }^{47} 2$ Enoch 23:4 pictures the angel Vereveil who commands Enoch to sit down. "You sit down; ${ }^{48}$ write everything...». And Enoch said, "And I sat down for a second period of 30 days and 30 nights, and I wrote accurately» $(23: 6) .{ }^{49}$ The theme of Enoch-Metatron's seat became a prominent motif in rabbinic tradition, where according to $b$. Hag. 15a, the privilege of «sitting» beside God was accorded solely to Metatron by virtue of his character as a «scribe»: for he was granted permission as a scribe to sit and write down the merits of Israel.

The tacit links between Enoch and Moses found in the early Enochic theophanic tradition later become openly articulated in rabbinic literature. In this later enunciation, as in the initial encounters, the familiar theophanic motif from the Exodus story again plays a crucial role. From 3 Enoch we learn that it is Enoch-Metatron, whose face once was transformed into fire, ${ }^{50}$ who is now the one ${ }^{51}$ who tells Moses about his shining visage: «At once

${ }^{46}$ In 1 Enoch 74:2 Enoch writes the instructions of the angel Uriel regarding the secrets of heavenly bodies and their movements. M. KNIBB, The Ethiopic Book of Enoch: A New Edition in the Light of the Aramaic Dead Sea Fragments. 2 vols (Oxford, 1978) Vol. 2. 173. Qumran Enochic fragments (4QEnGiants 14; 4QEn 92:1) picture Enoch as «the scribe of distinction» ספר פרש. Cf. J. T. Milik, The Books of Enoch: Aramaic Fragments of Qumran Cave 4 (Oxford, 1976) 261-262 and 305. In the Book of Jubilees Enoch is attested as «the first of mankind... who learned (the art of) writing, instruction, and wisdom and who wrote down in a book the signs of the sky...». J. C. VANDERKAM, The Book of Jubilees. 2 vols (Leuven, 1989) (CSCO, 510-511; Scriptores Aethiopici, 87-88) Vol. 2. 25-26.

${ }^{47} \mathrm{P}$. W. van der Horst also stresses unique features of Moses' enthronement in Ezekiel the Dramatist, which depart from Enochic and Merkabah imagery. He observes that «in Moses' vision, there is only one throne, God's. And Moses is requested to be seated on it, not at God's side but all alone. God leaves his throne. This scene is unique in early Jewish literature and certainly implies a deification of Moses». VAN DER Horst, Moses' Throne Vision... 25.

${ }^{48}$ Slav. гади.

49 ANDERSEN, 2 Enoch... 141.

${ }^{50} 3$ Enoch 15:1 depicts this radiant metamorphosis of Enoch-Metatron: «When the Holy One, blessed be he, took me to serve the throne of glory, the wheels of the chariot and all the needs of the Schekinah, at once my flesh turned to flame, my sinews to blazing fire, my bones to juniper coals, my eyelashes to lightning flashes, my eyeballs to fiery torches, the hairs of my head to hot flames, all my limbs to wings of burning fire, and the substance of my body to blazing fire». AlEXANDER, 3 Enoch... 267.

${ }^{51}$ Scholars observe that in Merkabah tradition Metatron is explicitly identified with the Face of God. Cf.: A. DE ConICK, Heavenly Temple Traditions and Valentinian Worship: A Case for First-Century Christology in the Second Century // The Jewish Roots of Christological Monotheism / Ed. C. C. Newman, J. R. Davila, G. S. Le- 
Metatron, Prince of the Divine Presence, said to Moses, Son of Amram, fear not! for already God favors you. Ask what you will with confidence and boldness, for light shines from the skin of your face from one end of the world to the other». ${ }^{52}$

\section{Conclusion}

The foregoing research has examined some extrabiblical materials related to the motif of the divine face found in Ex 33. The investigation has shown that the evolution of this motif in later traditions is dependent on the EnochMoses gestalt, which plays a prominent role in the Enochic theophanies of the divine face. This research, however, would not be complete without mentioning another important source which is also related to the traditions about the patriarch Enoch and the prophet Moses. This source is the priestly editor of the Pentateuch.

Much attention has been devoted to the peculiar interest of the priestly editor in anthropomorphic descriptions of the Deity. ${ }^{53} \mathrm{M}$. Weinfeld and T. Mettinger show that the Priestly source played a crucial role in promoting biblical theophanic traditions. In these traditions Moses' figure has occupied an important place. ${ }^{54}$

The Priestly source also was the locus where the enigmatic figure of Enoch for the first time appeared in its esoteric complexity, ${ }^{55}$ indicating that the priestly author was cognizant of the broader Enochic developments. Some scholars believe that perhaps it is «to some such developed Enoch tradition

WIS (Brill, 1999) (JSJ, 63) 329; D. J. HALPERIN, The Faces of the Chariot (Tübingen, 1988) (TSAJ, 16) 424-425.

523 Enoch 15B:5. Cf. AleXAnder, 3 Enoch... 304.

${ }^{53}$ On the issue of Old Testament's anthropomorphism see: J. BARR, Theophany and Anthropomorphism in the Old Testament // VT Suppl. 7 (1960) 31-38; J. HEMPEL, Die Grenzen des Anthropomorphismus Jahwes im Alten Testament // ZAW 57 (1939) 75-85; F. MichaELI, Dieu à l'image de l'homme: Étude de la notion anthropomorphique de Dieu dans l'Ancien Testament (Neuchâtel, 1950); E. JACOB, Théologie de l'Ancien Testament (Neuchâtel, 1955) 30ff.; M. C. A. KorPel, A Rift in the Clouds. Ugaritic and Hebrew Descriptions of the Divine (Münster, 1990) (UBL, 8) 87-590; T. N. D. Mettinger, The Dethronement of Sabaoth. Studies in the Shem and Kabod Theologies (Lund, 1982) (ConBOT, 18).

${ }^{54}$ Mettinger, The Dethronement of Sabaoth...; Weinfeld, Deuteronomy and the Deuteronomic School... 191-209.

55 The traditions about Enoch are different in $\mathrm{J}$ and P. For the discussion of the differences, see J. VANDERKAM, Enoch and the Growth of an Apocalyptic Tradition (Washington, 1984) (CBQMS, 16) 23-51; H. S. Kvanvig, Roots of Apocalyptic: the Mesopotamian Background of the Enoch Figure and of the Son of Man (NeukirchenVluyn, 1988) (WMANT, 61) 40-53. 
the author of Genesis is making reference when he emits his cryptic statements about Enoch in Genesis 5:22-24». ${ }^{56}$

Students of the Enochic tradition are now aware that the priestly editor was familiar with the peculiar Mesopotamian traditions ${ }^{57}$ which constituted a conceptual framework for Enoch's figure. ${ }^{58}$

In these Mesopotamian traditions a prototype of Enoch, Enmeduranki, is portrayed as a «translated» figure, the one «who sat in the presence (mahar $)^{59}$ of Shamash and Adad, the divine adjudicators $» .^{60}$ This reference to Enmeduranki's access to the glorious presence/face of the solar deity ${ }^{61}$ indicates

${ }^{56}$ M. Stone, Enoch, Aramaic Levi and Sectarian Origin // JSJ 19 (1988) 162.

${ }^{57}$ On the Mesopotamian traditions behind the Enoch's figure, see H. ZIMMERN, Urkönige und Uroffenbarung // E. SCHRADER, Die Keilinschriften und das Alte Testament. 2 vols (Berlin, 1902-1903) Vol. 2. 530-543; H. L. JANSEN, Die Henochgestalt: Eine vergleichende religionsgeschichtliche Untersuchung (Oslo, 1939) (Norske Videnskaps-Akademi i Oslo II. Hist.-Filos. Klasse, 1); P. Grelot, La légende d'Hénoch dans les apocryphes et dans la Bible: origine et signification // RSR 46 (1958) 5-26, 181-210; VANDERKAM, Enoch and the Growth of an Apocalyptic Tradition...; KvanVIG, Roots of Apocalyptic: the Mesopotamian Background of the Enoch Figure...

${ }^{58}$ Important witnesses to these traditions include the various versions of the socalled Sumerian antediluvian King List, the materials which dated from 1500 B.C.E. to 165 B.C.E. The List demonstrates a number of similarities with the genealogy of Genesis 5. One of its interesting details is that Mesopotamian kings, as well as patriarchs from Genesis' account, had extraordinary long reigns, ranging from 3,600 to 72,000 years. A second important parallel is that two versions of the List give ten kings, the last of whom is designated as the hero of the flood. It demonstrates a close resemblance to the role of Noah who occupies the tenth place in the list of Genesis 5 . J. VanderKam notes that «in the literature on Genesis 5 there is a well established tradition which holds that $\mathrm{P}$ modeled his pre-flood genealogy on a Mesopotamian list of antediluvian kings, the so-called Sumerian King List». VANDERKAM, Enoch and the Growth of an Apocalyptic Tradition... 26. An important character of the Sumerian King list is Enmeduranki (Enmeduranna), the king of Sippar, the city of the sungod Shamash. In three copies of the List he occupies the seventh place, which in Genesis' genealogy belongs to Enoch. Moreover, in other Mesopotamian sources Enmeduranki appears in many roles and situations which demonstrate remarkable similarities with Enoch's story. J. VanderKam's research shows that the priestly author was aware of these broader Mesopotamian traditions which served as a prototype for Enoch's figure, whose symbolical age of 365 years reflects the link between the patriarch and the solar cult of Shamash. VanderKam concludes that «the biblical image of Enoch is based on the Mesopotamian picture of Enmeduranki». Ibid. 50.

${ }^{59}$ In another text about Enmeduranki the same motif of the divine presence can be found: «...he may approach the presence (mahar) of Shamash and Adad...». W. G. LAMBERT, Enmeduranki and Related Matters // JCS 21 (1967) 132.

${ }^{60}$ Ibid. 128 and 130.

${ }^{61}$ On Mesopotamian solar symbolism and its influence on biblical concepts, including the concept of the divine panim cf. A. CAQUOT, La Divinité Solaire Ougari- 
that the later role of Enoch as Sar ha-Panim, the Prince of the Divine Presence or the Prince of the Face, ${ }^{62}$ was already present in its rudimentary form in the Mesopotamian traditions known to the priestly editor.

In the light of these observations the idea that Ex 33 could actually contain the original Enochic motif is not inappropriate. The implicit link between the Enochic account of the divine Presence and the Mosaic account of the divine panim may well reflect the conceptual world of the priestly editor, who often «has expressed his acquaintance with a fairly broad range of Mesopotamian traditions in remarkably few words». ${ }^{63}$

\begin{abstract}
The article examines the Enochic background of the imagery of the Divine Face found in Exodus 33. The study argues that Ex 33 could actually contain the original Enochic motif. In Mesopotamian traditions, a prototype of Enoch, Enmeduranki, is portrayed as a «translated» figure, the one who had access to the glorious presence/face of the solar deity. The implicit link between the Enochic account of the divine Presence and the Mosaic account of the divine panim found in Ex 33 may well reflect the conceptual world of the priestly editor, who often «has expressed his acquaintance with a fairly broad range of Mesopotamian traditions in remarkably few words».
\end{abstract}

tique // Syria 36 (1959) 90-101; B. JANOwsKI, Rettungsgewissheit und Epiphanie des Heils (Neukirchen-Vluyn, 1989) (WMANT, 59) Vol. 1. 105ff.; B. LANGER, Gott als «Licht» in Israel und Mesopotamien: Eine Studie zu Jes. 60:1-3.19f (Klosterneuburg, 1989) (Österreichische biblische Studien, 7); W. SMeliK, On Mystical Transformation of the Righteous into Light in Judaism // JSJ 26 (1995) 122-144; M. SмIтн, The Early History of God: Yahweh and the other Deities in Ancient Israel (San Francisco, 1990); M. Sмітн, The Near Eastern Background of Solar Language for Yahweh // JBL 109/1 (1990) 29-39; H. P. STÄHLI, Solare Elemente im Jahweglauben des Alten Testaments (Freiburg—Göttingen, 1985) (OBO, 66).

${ }^{62}$ Some scholars argue that the biblical concept of the divine face also has Mesopotamian roots. M. Fishbane and M. Smith show that the language of the Lord's shining face was part of Israel's inheritance from ancient Near Eastern culture. Cf. M. Fishbane, Form and Reformulation of the Biblical Priestly Blessing // JAOS 103 (1983) 115-21; M. SмIтH, «Seeing God» in the Psalms: The Background to the Beatific Vision in the Hebrew Bible // CBQ 50 (1988) 171-183. Fishbane stresses that «the various and abundant use of such imagery in ancient Near Eastern literature, particularly from Mesopotamia where it recurs in a wide range of genres, suggests that ancient Israel absorbed such imagery as part and parcel of its rich patrimony». FisHBANE, Form and Reformulation... 116.

${ }^{63}$ VANDER Kam, Enoch and the Growth of an Apocalyptic Tradition... 50. 